\title{
Development and in vitro evaluations of new decitabine nanocarriers for the treatment of acute myeloid leukemia
}

This article was published in the following Dove Press journal:

International Journal of Nanomedicine

Number of times this article has been viewed

\author{
Thomas Briot ${ }^{1,2}$ \\ Emilie Roger' \\ Nolwenn Lautram' \\ Alexis Verger ${ }^{1}$ \\ Anne Clavreul ${ }^{3,4}$ \\ Frederic Lagarce ${ }^{1,2}$ \\ 'Micro \& Nanomédecines \\ Translationelles - MINT, UNIV Angers, \\ INSERM 1066, CNRS 602I, Université \\ Bretagne Loire, MINT IBS-CHU, \\ ${ }^{2}$ Pharmacy Department, University \\ Hospital of Angers, ${ }^{3}$ Neurosurgery \\ Department, University Hospital \\ of Angers, ${ }^{4}$ CRCINA, INSERM, \\ Université de Nantes, Université \\ d'Angers, Angers, France
}

Correspondence: Frederic Lagarce MINT, UNIV Angers, INSERM I066, CNRS 602I, Université Bretagne Loire, MINT IBS-CHU, 4 rue Larrey, 49933 Angers Cedex 9, France Tel +3324I 353544 Fax +33241354084 Email frederic.lagarce@univ-angers.fr
Abstract: Decitabine is a hydrophilic drug that acts by hypomethylating DNA. Decitabine is used in Europe for the treatment of acute myeloid leukemia (AML) in patients aged $\geq 65$ years. However, it can only be administered intravenously due to very low oral bioavailability and a large distribution volume. Oral administration would allow outpatient treatment, improving quality of life and reducing treatment costs. The present study proposes to develop lipid nanocapsules (LNCs), originally designed for lipophilic drugs, to encapsulate decitabine. Two different formulations of LNCs were designed: LNCs based on a high proportion of Transcutol ${ }^{\circledR} \mathrm{HP}$ (THP-LNCs) and LNCs associated with a mixture of Transcutol ${ }^{\circledR} \mathrm{HP}$ and Tween ${ }^{\circledR} 80$ (THP-T80-LNCs). The second formulation had a diameter of $26.5 \pm 0.5 \mathrm{~nm}$, high encapsulation efficiency $(>85 \%)$, and a drug payload of $472 \pm 64 \mu \mathrm{g} / \mathrm{mL}$. Decitabine-loaded THP-T80-LNC cytotoxicity was evaluated on two AML cell lines depending on their decitabine resistance: HEL (not resistant) and HL-60 (resistant). The permeability of decitabine-loaded THP-T80-LNCs was also evaluated on Caco-2 cell monolayers. Decitabine cytotoxicity against HEL and HL-60 was higher when decitabine was loaded in THPT80-LNCs than when free. Apparent permeability on Caco- 2 cell monolayers was also increased, suggesting a potentially useful formulation to increase the oral bioavailability of decitabine.

Keywords: lipid nanocapsules, acute myeloid leukemia, decitabine, nanomedicine, nanoparticles, oral administration, $\mathrm{Caco} 2$ cells

\section{Introduction}

In 2012, the incidence of leukemia was estimated to be $2.5 \%$ of all cancers, excluding non-melanoma skin cancer, according to the International Agency for Research on Cancer. Acute myeloid leukemia (AML) is a common acute leukemia in older patients, accounting for $30 \%$ of adult leukemias. ${ }^{1}$ AML is caused by the overproduction of myeloblasts that accumulate in bone marrow, peripheral blood, and tissues, resulting in reduced production of normal bone marrow cells.

Comorbidities are often present in older AML patients, and best supportive care is preferred to the intensive chemotherapy used for younger patients. Thus, fewer patients aged $\geq 60$ years with newly diagnosed AML, associated with comorbidities, receive chemotherapy. ${ }^{2}$ In 2012, the European Medicines Agency (EMA) granted a marketing authorization, valid throughout the European Union, for the use of decitabine in AML patients aged $\geq 65$ years who are not candidates for standard induction chemotherapy due to age or comorbidities. Decitabine was previously approved in 2006 by the US Food and Drug Administration (FDA) for de novo or secondary myelodysplastic syndrome.

Decitabine (5-aza-2' deoxycytidine) was first described more than 40 years ago. ${ }^{3}$ It is a cytidine deoxynucleoside analog, which acts by inhibiting DNA methyltransferase, 
inducing DNA hypomethylation. To be active, decitabine needs to be transported into cells by an equilibrativenucleoside-transport (hENT) system and converted into its triphosphate form. Decitabine is a hydrophilic drug ( $\log P=-2.2)$, with a short half-life (25 minutes), and is sensitive to harsh conditions. For example, the glycosidic bond of azanucleosides is cleaved under acidic conditions, and there is a rapid opening of the 5-azacytosine ring under alkaline conditions. ${ }^{3,4}$

The European marketed formulation of decitabine (Dacogen $^{\circledR}$; Janssen-Cilag, Beerse, Belgium) is a sterile freeze-dried powder. Excipients are potassium dihydrogen phosphate, sodium hydroxide, and hydrochloric acid for $\mathrm{pH}$ adjustment. There is no specific tissue targeting, resulting in wide distribution, ${ }^{5}$ suggesting that decitabine is distributed into tissues outside the plasma compartment.

In AML, decitabine is administered via intravenous (IV) infusion, every day, for 5 days at $20 \mathrm{mg} / \mathrm{m}^{2}$, every 4 weeks. The increase of median survival (2.7 months) is modest, but was considered to be meaningful by the EMA in the context of AML in older patients without alternative treatment. ${ }^{6}$ A Phase II clinical trial (NCT01786343) is ongoing with modified dosing schedules to increase the cytotoxic activity of the drug.

Various approaches have been developed to modify pharmacokinetic parameters of decitabine to enhance its oral bioavailability and therapeutic index, including the use of nanocarriers. For example, Vijayaraghavalu and Labhasetwar have tested decitabine-loaded nanogels for their ability to protect decitabine from degradation and enhance its intracellular uptake. ${ }^{7}$ Cui et al have developed decitabine conjugates incorporated into micelles to enhance the activity of an associated drug, temozolomide, against glioblastoma cells, ${ }^{8}$ Neupane et $\mathrm{l}^{9,10}$ have developed lipid-decitabine conjugate nanoparticles for oral administration. All these studies used organic solvents for chemical modification of the drug or the process of nanoparticle formulation., ${ }^{9} 10$ However, organic solvents may cause new toxicities in clinical applications.

Replacing IV administration of decitabine with oral administration may improve treatment acceptability by patients and facilitate the administration with possible treatment at home with no requirement of a medical team. ${ }^{11}$ Various parameters influence the oral absorption of drugs, such as intestinal permeability, solubility in aqueous media, and stability in intestinal fluids.

Our laboratory has developed lipid nanocapsules (LNCs) based on a solvent-free process and prepared by a low energy phase inversion process. ${ }^{12}$ Lipophilic drugs have already been encapsulated into LNCs, such as paclitaxel, docetaxel, SN38, etoposide, hydroxytamoxifen, miltefosine, or a ferrocenyl complex. ${ }^{12-17}$ Hydrophilic drugs, such as fondaparinux ${ }^{18}$ or DNA and siRNA, ${ }^{19,20}$ have also been encapsulated, and reverse micelles associated with LNCs containing doxorubicin hydrochloride or erlotinib hydrochloride have been developed. ${ }^{21,22}$ Encapsulation into LNCs has modified the pharmacokinetic parameters of DNA when encapsulated in stealth LNCs, ${ }^{20}$ or of miltefosine, an antischistosomal drug, by increasing its time to reach the maximal concentration and increasing its activity against Shistosoma mansoni. ${ }^{16}$ Moreover, several publications have reported the advantages of LNCs for oral administration. It has been shown that LNCs are able to protect encapsulated SN38 in intestinal fluids and enhance its permeability across a Caco- 2 cell monolayer. ${ }^{14}$ LNCs are also able to modify oral bioavailability of encapsulated drugs, such as paclitaxel and fondaparinux. ${ }^{18,23}$

The aim of the present study was to adapt the formulation of LNCs to encapsulate decitabine and evaluate its efficacy in AML cell models. The permeability of encapsulated decitabine across an intestinal barrier model was evaluated to estimate the potential oral administration of the formulation developed.

\section{Materials and methods Chemicals}

Decitabine was purchased from LC Laboratories ${ }^{\circledR}$ (Woburn, MA, USA). Labrafac ${ }^{\circledR}$ WL1349 (caprylic-capric acid triglycerides), Labrafil ${ }^{\circledR}$ M1944CS (oleoyl macrogol-6 glycerides), Peceol ${ }^{\circledR}$ (glycerol mono-oleates), and Transcutol ${ }^{\circledR}$ HP (THP) (highly purified diethylene glycol monoethyl ether) were kindly provided by Gattefossé (Saint-Priest, France). Lipoïd ${ }^{\circledR}$ S75-3 (soybean lecithin: 69\% phosphatidylcholine and 10\% phosphatidylethanolamine) and Kolliphor ${ }^{\circledR}$ HS15 (mixture of free polyethylene glycol [PEG] 660 and PEG 660 hydroxystearate) were kindly supplied by Lipoïd ${ }^{\circledR}$ and BASF, respectively (Ludwigshafen, Germany). Deionized water was obtained from a Milli-Q plus system (Merck-Millipore, Darmstadt, Germany). Sodium chloride and disodium hydrogen phosphate were purchased from Prolabo (Fontenay-Sous-Bois, France) and sucrose was purchased from Merck-Millipore. Sodium phosphate dibasic dodecahydrate, potassium dihydrogen phosphate, formic acid, ammonium acetate, Triton ${ }^{\circledR} \mathrm{X}-100$, Tween $^{\circledR} 80$, $\operatorname{Span}^{\circledR} 80$, and formic acid were obtained from Sigma-Aldrich (St Quentin-Fallavier, France). Captex $^{\circledR} 8000$ (glyceryl tricaprylate) was a gift from Abitec Corp. (Saint-Quentin Fallavier, France).

Absolute ethanol, methanol ULC/MS grade, acetonitrile, and LC-MS grade water were purchased from Biosolve (Dieuze, France). Acetone was purchased from VWR (Fontenay-sous-Bois, France). 


\section{Analytical methods}

Analysis of decitabine by ultra-high-performance liquid chromatography (UPLC-UV)

An UPLC-UV method was developed to quantify decitabine in solubility and formulation studies. The apparatus consisted of an UPLC Acquity ${ }^{\circledR}$ H-Class Bio (Waters, Saint-Quentinen-Yvelines, France) composed of a quaternary solvent manager, a sample manager with the temperature fixed at $4^{\circ} \mathrm{C}$, a photo diode array detector, operating between 200 and $400 \mathrm{~nm}$, and a column manager with the temperature fixed at $25^{\circ} \mathrm{C}$. The system was managed by Empower ${ }^{\circledR} 3$ software (Waters). The column used was an Acquity ${ }^{\circledR}$ UPLC HSS T3 $2.1 \times 50 \mathrm{~mm}, 1.8 \mu \mathrm{m}$ (Waters). Detection was fixed at $239 \mathrm{~nm}$. The mobile phase consisted of a gradient elution (Table S1) composed of a mixture of water (A) and methanol (B). The injection volume was set to $5 \mu \mathrm{L}$.

Decitabine solutions were systematically prepared by dissolving a sufficient quantity in a phosphate-buffered solution (PBS, $\mathrm{pH} 7.0)$ composed of a 50:50 (v/v) mixture of dibasic sodium phosphate dodecahydrate solution $(26 \mathrm{mM})$ and potassium dihydrogen phosphate $(67 \mathrm{mM})$. The runtime of the analysis was 10 minutes.

The method was validated according to ICH Q2 R1 standards. ${ }^{24}$ Linearity of the method was evaluated by a calibration curve composed of seven calibration points between 2.5 and $50 \mu \mathrm{g} / \mathrm{mL}$. Calibration curves were performed three times on 3 different days. The correlation coefficient $\left(\mathrm{r}^{2}\right)$ of the mean calibration curve had to be $>0.995$.

Accuracy of the method was assessed by making nine determinations of three concentrations $(5,20$, and $40 \mu \mathrm{g} / \mathrm{mL})$ three times a day, for 3 days. Accuracy was determined as the difference between the mean measured value and the accepted true value. Accuracy, for each concentration, had to be $<5 \%$ from the accepted true value to be accepted.

Repeatability was assessed by measuring a $10 \mu \mathrm{g} / \mathrm{mL}$ solution six times a day. Intermediate precision was evaluated by measuring this solution six times a day for 3 days. Repeatability and intermediate precision were measured using the standard deviation, which had to be $<5 \%$ to be accepted.

The limit of detection (LOD) and limit of quantification (LOQ) were based on the standard deviation of the response and the slope and were determined as follows:

$$
\mathrm{LOD}=\frac{3.3 \sigma}{\mathrm{S}} \text { and } \mathrm{LOQ}=\frac{10 \sigma}{\mathrm{S}}
$$

where $\sigma$ is the standard deviation of the response of 10 blanks and $\mathrm{S}$ is the slope of the calibration curve.

\section{Analysis of decitabine by LC-MS/MS}

An LC-MS/MS method was developed to quantify lower amounts of decitabine within the linear range of UPLC-UV, in formulations and in vitro decitabine release studies. The LC-MS/MS method was developed on an Alliance ${ }^{\circledR} 2695$ system (Waters) with a $150 \times 2 \mathrm{~mm}, 3 \mu \mathrm{m}$ Nucleodur ${ }^{\circledR}$ HILIC column (Macherey Nagel, Hoerdt, France), containing an ammonium-sulfonic acid-modified silica. The temperature was fixed at $25^{\circ} \mathrm{C}$. The mobile phase consisted of a mixture of (A) $0.1 \%$ formic acid in $10 \mathrm{mM}$ ammonium acetate and (B) $0.1 \%$ formic acid in acetonitrile. A gradient mode was used (Table S2). The injection volume was set at $6 \mu \mathrm{L}$. The total HPLC effluent was directed into a Quattro Micro ${ }^{\circledR}$ triple quadrupole mass spectrometer (Waters). Ionization was achieved using electrospray in positive ion mode. The mass spectrometer was operated in multiple reaction monitoring mode. The $(\mathrm{M}-\mathrm{H})+\mathrm{m} / \mathrm{z}$ transition for decitabine was 229.0 > 113.0. The entire system was controlled by Masslynx $^{\circledR}$ software (Waters).

Decitabine was diluted in methanol to obtain a 7-point calibration curve between 2.5 and $500 \mathrm{ng} / \mathrm{mL}$. The LC-MS/MS method was also validated according to the ICH Q2 R1 validation method. ${ }^{24}$ The same validation protocol was applied as that used for the UPLC-UV method. Accuracy was determined at three concentrations $(10,100$, and $400 \mathrm{ng} / \mathrm{mL})$ and precision at $200 \mathrm{ng} / \mathrm{mL}$. The requirements were the same as for the UPLC-UV method (5\% for each).

LOD and LOQ were based on the standard deviation of the response and the slope, as described above.

\section{Solubility study}

Decitabine $(5 \mathrm{mg}$ ) was added to $1 \mathrm{~g}$ of oil, co-solvent, surfactant, or a mixture of them. Preparations were sonicated at room temperature for 2 hours or placed at $25^{\circ} \mathrm{C}$ under magnetic stirring for 72 hours to facilitate solubilization. For solubility studies on mixtures of oil, surfactant, and co-solvent, magnetic stirring was performed at $50^{\circ} \mathrm{C}$ for 2 hours or the mixtures were sonicated for 2 hours at room temperature. All preparations were then centrifuged at $9,000 \times g$ for 10 minutes. Supernatants were collected and filtered using a $0.22 \mu \mathrm{m}$ Millex ${ }^{\circledR}$ (MerckMillipore). Filtrates were analyzed by the UPLC-UV method described above. When the solubility was over $2.0 \mathrm{mg} / \mathrm{g}$, the experiment was repeated two more times.

\section{LNC formulations}

Formulation of LNCs with Transcutol ${ }^{\circledR}$ HP (THP-LNCs)

LNCs were obtained according to the formulation process developed in our laboratory, based on a phase inversion 
process $^{12}$ and a formulation using THP was prepared. ${ }^{14,15}$ This formulation was modified to increase the proportion of THP to improve the quantity of decitabine incorporated into the decitabine-loaded formulation. Concentrations of Lipoïd ${ }^{\circledR} \mathrm{S} 75-3$, Kolliphor ${ }^{\circledR} \mathrm{HS} 15$, and $\mathrm{NaCl}$ in water before the dilution step were set to $2.9 \%(\mathrm{w} / \mathrm{w}), 19.4 \%(\mathrm{w} / \mathrm{w})$, and $1.9 \%(\mathrm{w} / \mathrm{w})$, respectively. A ternary diagram was used to plot the possible proportions of Labrafac $^{\circledR}$ WL1349, Labrafil ${ }^{\circledR}$ M1944CS, and THP. A formulation was considered to be acceptable if the size of the particle was $<100 \mathrm{~nm}$ and the polydispersity index $(\mathrm{PI})<0.20$.

Briefly, Labrafac ${ }^{\circledR}$ WL1349, Labrafil ${ }^{\circledR}$ M1944CS, and THP were mixed with Lipoïd ${ }^{\circledR}$ S75-3 by magnetic stirring and heated to $80^{\circ} \mathrm{C}$. The mixture was cooled to room temperature and other components were added: Kolliphor ${ }^{\circledR} \mathrm{HS} 15, \mathrm{NaCl}$, deionized water. Three heating cycles under magnetic stirring were performed between $40^{\circ} \mathrm{C}$ and $90^{\circ} \mathrm{C}$. During the last cooling cycle, when the inversion phase was detected, tempering was induced with $5 \mathrm{~mL} 4^{\circ} \mathrm{C}$ water. Magnetic stirring was maintained for 5 minutes at room temperature and the suspension of THP-LNCs was filtered using a $0.22 \mu \mathrm{m}$ polyethersulfone filter (Merck-Millipore) to remove potential residual components.

The optimal formulation, corresponding to the maximum quantity of THP, was selected.

\section{Decitabine-loaded THP-LNCs}

Decitabine was first solubilized in THP at a concentration of $2.5 \mathrm{mg} / \mathrm{g}$ by ultrasonication for 2 hours, and decitabinesolubilized in THP was then incorporated into the optimized formulation (as described above) during the last cooling cycle, just before tempering.

\section{Formulation of LNCs with a mixture of THP and Tween ${ }^{\circledR} 80$ (THP-T80-LNCs)}

First, a mixture of THP and Tween ${ }^{\circledR} 80$ (THP-T80) (w/w) was made. Then, an LNC formulation composed of Kolliphor ${ }^{\circledR}$ HS15 (39.3\% w/w), NaCl (1.8\% w/w), Labrafac ${ }^{\circledR}$ WL1349 $(17.2 \% \mathrm{w} / \mathrm{w})$, and water $(41.7 \% \mathrm{w} / \mathrm{w})$ was prepared by three heating cycles under magnetic stirring performed between $65^{\circ} \mathrm{C}$ and $95^{\circ} \mathrm{C}$. During the last cooling cycle, at $85^{\circ} \mathrm{C}$, the THP-T 80 mixture was introduced $(30 \% \mathrm{w} / \mathrm{w}$ total composition) and tempering was induced at $75^{\circ} \mathrm{C}$ with $5 \mathrm{~mL} 4^{\circ} \mathrm{C}$ water. Magnetic stirring was maintained for 5 minutes at room temperature.

\section{Decitabine-loaded THP-T80-LNCs}

A sufficient quantity of decitabine was incorporated under magnetic stirring at $50^{\circ} \mathrm{C}$ for 2 hours in THP-T80 mixture to obtain a concentration of $4.2 \mathrm{mg} / \mathrm{g}$. Decitabine was then incorporated into the THP-T80-LNC formulation (described in "Formulation of LNCs with a mixture of THP and Tween ${ }^{\circledR}$ 80 (THP-T80-LNCs)" section) during the last cooling cycle, just before tempering.

\section{Characterization of LNC formulations}

\section{Size and PI measurement}

Mean particle size and PI were determined by dynamic light scattering on a Zetasizer ${ }^{\circledR}$ Nano serie DTS 1060 (Malvern Instruments S.A., Worcestershire, UK). PI was used as a measure of size distribution. The formulations were diluted 1:60 (v/v) in deionized water. Three consecutive measurements were performed.

\section{Transmission electronic microscopy (TEM)}

Size and morphology of blank THP-T80-LNCs were investigated using a JEOL JEM 1400 (JEOL, Croissy Sur Seine, France) operating at $120 \mathrm{kV}$. A sample of particle suspension was placed on a copper grid and water was evaporated at $40^{\circ} \mathrm{C}$ for one night prior to imaging by TEM.

\section{Determination of encapsulation efficiency and drug loading}

Total (free and encapsulated) quantities of decitabine in the formulations were evaluated by UPLC-UV (THP-LNCs) or LC-MS/MS (THP-T80-LNCs). Formulations were diluted 1:20 (v/v) in Triton ${ }^{\circledR}$ X-100 diluted 10 times in PBS pH 7.0 for the UPLC-UV method, and 1:5,000 (v/v) in methanol for the LC-MS/MS method. Triton ${ }^{\circledR} \mathrm{X}-100$ and methanol were used to release decitabine from LNCs by breaking them.

The formulations were subjected to ultracentrifugation in a sucrose gradient to separate encapsulated and freedecitabine. The formulation $(200 \mu \mathrm{L})$ was first placed in a tube, followed by a slow addition of $400 \mu \mathrm{L}$ of a $50 \%$ (w/v) sucrose solution, $600 \mu \mathrm{L}$ of a $20 \%(\mathrm{w} / \mathrm{v})$ sucrose solution, and finally $600 \mu \mathrm{L}$ deionized water. The tubes were centrifuged at $214,000 \times g$ for 1.5 hours at $4{ }^{\circ} \mathrm{C}$ in an Optima TLX ultracentrifuge (Beckman, Villepinte, France), equipped with a TLS 55 rotor.

After 1.5 hours, each fraction was collected and $100 \mu \mathrm{L}$ of each diluted $1: 10 \mathrm{v} / \mathrm{v}$ in Triton ${ }^{\circledR} \mathrm{X}-10$ and decitabine quantification performed by the UPLC-UV method for decitabine-loaded THP-LNCs. The encapsulation efficiency was determined by LC-MS/MS for decitabine-loaded THPT80-LNCs. Each fraction was diluted in water instead of Triton ${ }^{\circledR}$ X-10 and then in methanol 1:20 (v/v).

Decitabine not encapsulated in the formulation was found in the sediment fraction after ultracentrifugation, 
corresponding to the $50 \%$ sucrose $(\mathrm{w} / \mathrm{v})$ fraction, whereas encapsulated decitabine was found in the supernatant fraction, corresponding to the aqueous fraction.

The encapsulation efficiency was defined as:

Encapsulation efficiency $(\%)=$

$\frac{\text { Total decitabine }- \text { Decitabine not encapsulated }}{\text { Total decitabine }} \times 100$

The experimental drug payload was defined as:

Drug payload $(\mu \mathrm{g} / \mathrm{mL})=$ Total decitabine $(\mu \mathrm{g} / \mathrm{mL})$ $\times$ Encapsulation efficiency $(\%)$

\section{Freeze-drying of decitabine-loaded THP-T80-LNCs} After formulation, a 40\% (w/v) sucrose solution (cryoprotectant) was introduced to THP-T80-LNCs at a $1: 1 \mathrm{v} / \mathrm{v}$ ratio and a freeze-drying cycle performed (Alpha 1-4 LSC, Christ, Darmstadt, Germany). Formulations were conserved at $-20^{\circ} \mathrm{C}$. The water volume removed after freeze-drying was evaluated by weighing formulations before and after the process. Mean particle size, PI, encapsulation efficiency, and drug loading were determined after reconstitution with $200 \mu \mathrm{L}$ water.

\section{In vitro release study}

The release kinetics of decitabine-loaded THP-T80-LNCs were evaluated in PBS pH 7.4. About $1 \mathrm{~mL}$ of decitabineloaded THP-T80-LNCs was placed in a Float-a-Lyzer ${ }^{\circledR}$ (Spectrum labs, CA, USA) (100 kDa) completely submerged in a beaker containing $150 \mathrm{~mL}$ PBS to reach the "sink" conditions, at $37^{\circ} \mathrm{C}$ for 24 hours, under agitation. A free-decitabine solution, with a concentration equivalent to the concentration of decitabine-loaded THP-T80-LNC was used as a control. A $40 \mu \mathrm{L}$ sample of the PBS was removed at defined time points and replaced with PBS. The experiment was performed in triplicate. Samples were quantified by LC-MS/MS.

\section{Decitabine stability in human plasma}

Decitabine stability in human plasma from healthy volunteers was performed to evaluate its relative degradation over time. Decitabine-loaded THP-T80-LNCs $(100 \mu \mathrm{L})$ were mixed with plasma $(1.6 \mathrm{~mL})$ at $37^{\circ} \mathrm{C}$ for 6 hours, under agitation. A free-decitabine solution, with a concentration equivalent to the concentration of decitabine-loaded THP-T80-LNCs was used as a control. A $40 \mu \mathrm{L}$ sample of plasma was removed at 1, 4, and 6 hours and mixed with acetonitrile. Samples were then centrifuged 10 minutes at 9,500× $g$ (Centrifuge 5810 R; Eppendorf, Montesson, France). Supernatant was then quantified by LC-MS/MS after a dilution in methanol $(1 / 10)$. The experiment was performed in triplicate.

\section{Cell experiments}

In vitro cell viability

The toxicity of decitabine-loaded THP-T80-LNCs was compared to free-decitabine on the human erythroleukemia cell line (HEL) and human promyelocytic leukemia cells (HL-60) (LGC Standards, Molsheim, France). HEL cells were maintained in Roswell Park Memorial Institute 1640 (RPMI) medium (LGC Standards), containing 10\% fetal bovine serum (FBS) (Gibco, Fisher Scientific France, Illkirch, France) and 1\% antibiotics (Sigma-Aldrich) and HL-60 cells were maintained in Iscove's Modified Dulbecco's Medium (LGC Standards), containing 20\% FBS and 1\% antibiotics, as recommended by the supplier. Each cell line was maintained in a humidified incubator with an atmosphere containing 5\% $\mathrm{CO}_{2}$ at $37^{\circ} \mathrm{C}$.

For viability assays, cells were plated in 96-well plates at densities of $1 \times 10^{4}$ cells/well (HEL) or $1.5 \times 10^{4}$ cells/well (HL-60). After 24 hours, cells were treated with free-decitabine or decitabine-loaded THP-T80-LNCs to reach decitabine concentrations of $1-1,000 \mathrm{nM}$ (HEL) or 200-4,000 nM (HL-60). Blank THP-T80-LNCs were also tested with the same excipient concentrations as for decitabine-loaded THP-T80-LNCs. Cells cultured with medium alone were considered to correspond to $100 \%$ viability. After 72 hours, plates were centrifuged, culture medium removed, and cell pellets frozen at $-80^{\circ} \mathrm{C}$ until assayed. Cell survival was estimated with the CyQUANT ${ }^{\circledR}$ cell proliferation assay kit, according to the manufacturer's instructions (Fisher Scientific). Three independent experiments were conducted, each with quadruplicate samples. The concentration giving $50 \%$ inhibition (IC50) of the cell viability was calculated according to Reed and Muench. ${ }^{25}$

\section{In vitro transepithelial transport}

The human colon adenocarcinoma cell line (Caco-2) (ATCC, Manassas, VA, USA) was used at passage 30. Cells were cultured in Dulbecco's Modified Eagle's Medium (DMEM, high glucose; Lonza, Verviers, Belgium), supplemented with $15 \%$ (v/v) FBS, $1 \%$ (v/v) non-essential amino acids (SigmaAldrich), 1\% (v/v) sodium pyruvate (Sigma-Aldrich), and $1 \%$ antibiotics in a humidified incubator with an atmosphere of $5 \% \mathrm{CO}_{2}$ at $37^{\circ} \mathrm{C}$. Cells were plated in a Transwell ${ }^{\circledR}$ cell culture chamber (Corning Costar, NY, USA) at a density of $1 \times 10^{5}$ cells/insert $\left(0.4 \mu \mathrm{m}\right.$ pore size, $1.12 \mathrm{~cm}^{2}$ growth area). The culture medium $(0.5 \mathrm{~mL}$ per insert and $1.5 \mathrm{~mL}$ per well) was replaced every 2 days for the first 2 weeks and every 
day for the last 7 days. After 21 days, cell monolayers were obtained and used.

Before the experiment, cells were washed with Hanks Balanced Salt Solution (HBSS) (Lonza) and mixed with $10 \mathrm{mM}$ Hepes (Sigma-Aldrich), twice, for 10 minutes at $37^{\circ} \mathrm{C}$. The transepithelial electrical resistance (TEER) of the monolayer was assessed before and after the experiment using a Millicell ${ }^{\circledR}$ ER system (Merck-Millipore). Only cell monolayers with a TEER over $250 \Omega / \mathrm{cm}^{2}$ were used.

Free-decitabine or decitabine-loaded in THP-T80-LNCs ( $20 \mu \mathrm{M}, 0.5 \mathrm{~mL}$ ) were then added to the cell monolayers and $1.5 \mathrm{~mL}$ HBSS-Hepes buffer added to the basolateral side ( $n=4$ for each condition).

After 2 and 4 hours in a humidified incubator at $37^{\circ} \mathrm{C}$, $5 \% \mathrm{CO}_{2}$, samples from the apical and basolateral side were removed and the decitabine concentration evaluated by LC-MS/MS. The apparent permeability coefficient $\left(\mathrm{P}_{\text {app }}\right)$ was then calculated according to the following equation:

$$
\mathrm{P}_{\text {app }}=\frac{\mathrm{dQ}}{\mathrm{dt}} \times \frac{1}{A Q i}
$$

where $\mathrm{dQ} / \mathrm{dt}$ is the rate of drug appearance on the basolateral side $(\mu \mathrm{g} / \mathrm{s}) ; Q i$ is the initial quantity of decitabine on the apical side $(\mu \mathrm{g}) ; A$ is the surface area of the monolayer $\left(\mathrm{cm}^{2}\right)$.

\section{Statistical analysis}

Results are expressed as mean values \pm standard deviation (SD) or standard error of the mean (SEM) for the cell studies. A Kruskal-Wallis test was used for statistical analysis, $p<0.05$ was considered to be statistically significant.

\section{Results}

\section{Validation of analytical methods UPLC-UV method}

The retention time of decitabine was 1.4 minutes, the peak was symmetric and well defined (Figure S1). The mean calibration curve of the method for the range of $2.5-50 \mu \mathrm{g} / \mathrm{mL}$, determined on 3 different days was:

$$
y=1.237 \times 10^{4} x-1.168 \times 10^{4}
$$

where $y$ is the area under the curve and $x$ is the amount of decitabine.

The correlation coefficient $\left(\mathrm{r}^{2}\right)$ of the mean calibration curve was 0.997 , indicating that the method was linear.
The accuracy of the method was $2.9 \%, 2.8 \%$, and $0.6 \%$ at 5,20 , and $40 \mu \mathrm{g} / \mathrm{mL}$, respectively. Repeatability of the method was systematically inferior to $4.0 \%$ and intermediate precision $2.6 \%$. Accuracy, repeatability, and intermediate precision were thus compatible with the requirements.

The LOD and LOQ were 0.1 and $0.3 \mu \mathrm{g} / \mathrm{mL}$, respectively.

\section{LC-MS/MS method}

The retention time of decitabine was 3.5 minutes (Figure S1). The linearity of the method between 2.5 and $500 \mathrm{ng} / \mathrm{mL}$ gave an $r^{2}$ value that was systematically $>0.998$. The mean calibration curve of the method determined on 3 different days was:

$$
y=43,988 x-8,184
$$

where $y$ is the area under the curve and $x$ is the amount of decitabine.

The accuracy of the method was $2.8 \%,-4.4 \%$, and $-1.5 \%$ at 10,100 , and $400 \mathrm{ng} / \mathrm{mL}$ respectively. Repeatability of the method was systematically inferior to $5.0 \%$ and intermediate precision $3.7 \%$. The accuracy, repeatability, and intermediate precision were compatible with the requirements.

The LOD and LOQ were 0.04 and $0.11 \mathrm{ng} / \mathrm{mL}$, respectively.

\section{Solubility studies}

Decitabine solubility in several oils, co-solvents, and surfactants were evaluated at $0.5 \% \mathrm{w} / \mathrm{w}$ by an ultrasonic method for 2 hours or magnetic stirring for 72 hours, at room temperature. For an excipient mixture, magnetic stirring was performed for 2 hours at $50^{\circ} \mathrm{C}$ instead of 72 hours at $25^{\circ} \mathrm{C}$. Among the nine oils, co-solvents, surfactants, or mixtures, only the THP and THP-T80 mixture were able to solubilize decitabine (Table 1). Moreover, concentrations after 72 hours were systematically less than those after 2 hours. THP, a co-solvent already used in LNC formulations solubilized $2.5 \mathrm{mg} / \mathrm{g}$ of decitabine. The THP-T80 mixture provided maximum solubilization of decitabine (4.7 mg/g).

THP and THP-T80 mixtures were used for further formulation investigations.

\section{Decitabine formulations}

Two decitabine formulations were tested: decitabine-loaded THP-LNCs and decitabine-loaded THP-T80-LNCs. 
Table I Solubility of decitabine in various oils, surfactants, or co-solvents after 2 hours in an ultrasonic bath at room temperature or 72 hours under magnetic stirring at $25^{\circ} \mathrm{C}$ ( 2 hours at $50^{\circ} \mathrm{C}$ for excipient mixtures)

\begin{tabular}{|c|c|c|}
\hline Medium & $\begin{array}{l}\text { Ultrasonic bath } \\
(\mathrm{mg} / \mathrm{g})\end{array}$ & $\begin{array}{l}\text { Magnetic stirring } \\
(\mathrm{mg} / \mathrm{g})\end{array}$ \\
\hline Captex $^{\circledR} 8000$ & 0.0 & 0.0 \\
\hline THP* & $2.5 \pm 0.2$ & 0.3 \\
\hline Tween $^{\circledR} 80$ & 0.8 & 0.5 \\
\hline Peceol $^{\circledR}$ & 0.0 & 0.0 \\
\hline Span ${ }^{\circledR} 80$ & 0.0 & 0.0 \\
\hline Labrafi ${ }^{\otimes}$ MI944CS & 0.2 & 0.1 \\
\hline THP-T80 (50:50 w/w)* & 1.5 & $4.7 \pm 0.4$ \\
\hline Tween $^{\circledR} 80 /$ Labrafac $^{\circledR}$ WLI349 & 1.0 & 1.0 \\
\hline Span $^{\circledR}$ 85/Labrafac ${ }^{\circledR}$ WLI349 & 0.0 & 0.4 \\
\hline
\end{tabular}

Notes: The measurement was repeated three times if the first solubility was $>2.0 \mathrm{mg} / \mathrm{g}$. Results are expressed as the mean $\pm \mathrm{SD}(*)$.

Abbreviations: THP, Transcutol ${ }^{\circledR} \mathrm{HP}$; T80, Tween $^{\circledR} 80$.
The first formulation designed was a new THP-LNC formulation with a higher proportion of THP to increase the quantity of decitabine in the decitabine-loaded formulation. Nineteen formulations were tested (Figure 1). The ternary diagram shows that no formulation with a size $<100 \mathrm{~nm}$ and/or a PI $<0.20$ was obtained when the proportion of Labrafac $^{\circledR}$ WL1349 $>20 \%$. It was necessary to increase the proportion of Labrafil ${ }^{\circledR}$ M1944CS and decrease that of Labrafac ${ }^{\circledR}$ WL1349 to increase the proportion of THP.

Finally, formulation 18 (F18) was chosen for its size of $<100 \mathrm{~nm}(32.6 \mathrm{~nm})$ and PI of $<0.20(0.08)$. The quantity of Lipoïd ${ }^{\circledR}$ S75-3 was reduced from 150 to $100 \mathrm{mg}$, because filtration was difficult using a $0.22 \mu \mathrm{m}$ filter. The final optimized proportions were $24.7 \%(\mathrm{w} / \mathrm{w})$ THP, $16.5 \%(\mathrm{w} / \mathrm{w})$ Labrafil ${ }^{\circledR}$ M1944CS, 2.0\% (w/w) Lipoïd ${ }^{\circledR} 75-3,19.6 \%$ (w/w)

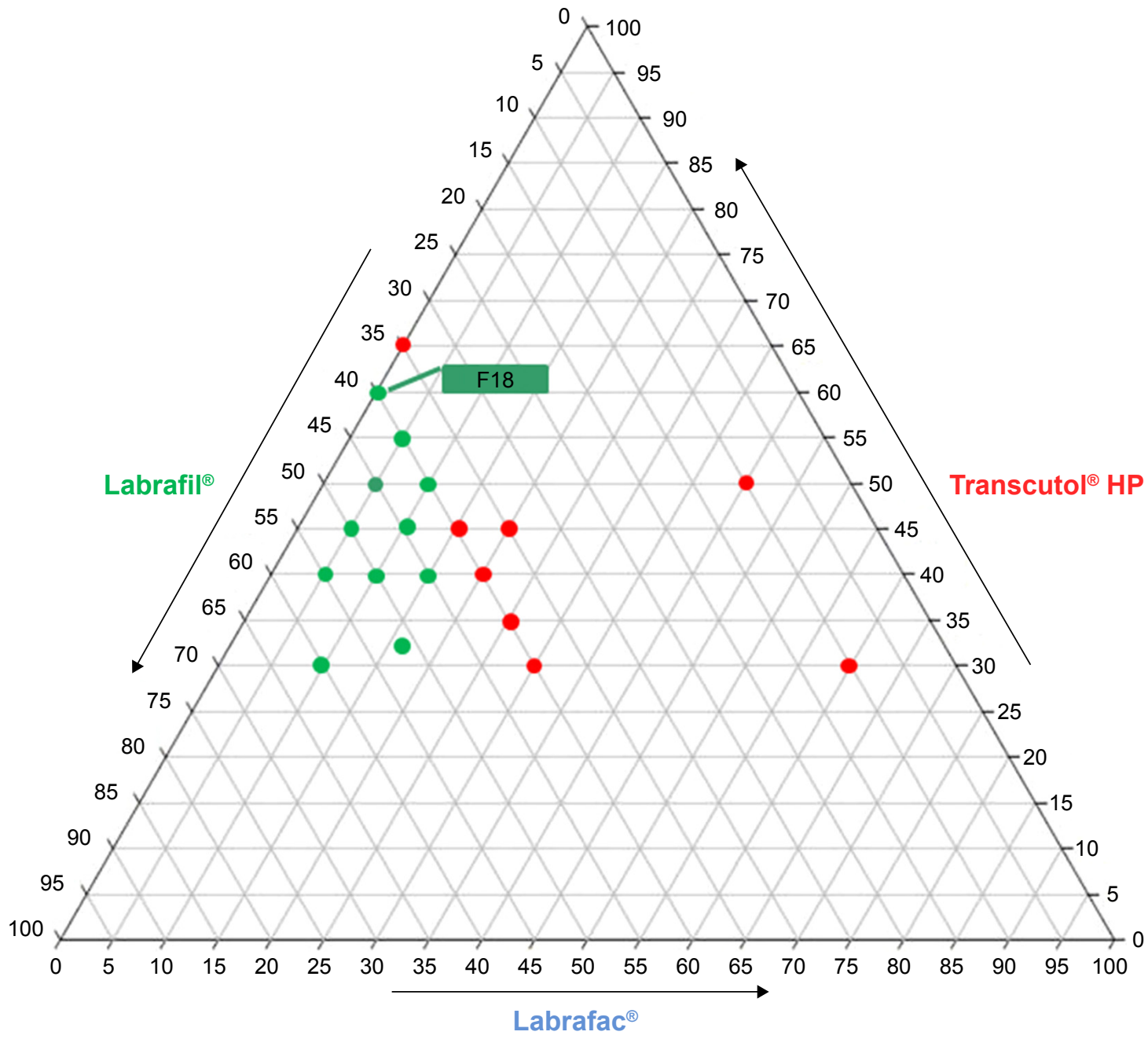

Figure I Ternary diagram of the optimization of THP-LNCs.

Notes: Green points correspond to formulations for which the PI was $<0.20$ and the size $<100 \mathrm{~nm}$ and red points to those for which the size was $>100 \mathrm{~nm}$ and/or the PI was $>0.20$. Formulation FI8 was the most highly optimized.

Abbreviations: LNC, lipid nanocapsule; THP, Transcutol ${ }^{\circledR} \mathrm{HP}$; PI, polydispersity index. 
Table 2 Physico-chemical characteristics of blank and decitabine-loaded LNC formulations

\begin{tabular}{|c|c|c|c|c|c|}
\hline LNC formulations & Size $(n m)$ & $\mathbf{P I}$ & $\begin{array}{l}\text { Total decitabine } \\
\text { concentration }(\mu \mathrm{g} / \mathrm{mL})\end{array}$ & $\begin{array}{l}\text { Encapsulation } \\
\text { efficiency (\%) }\end{array}$ & $\begin{array}{l}\text { Drug payload } \\
(\mu \mathrm{g} / \mathrm{mL})\end{array}$ \\
\hline Blank LNCs-THP & $33.6 \pm 1.6$ & $0.09 \pm 0.01$ & - & - & - \\
\hline LNCs-THP & $33.6 \pm 1.0$ & $0.08 \pm 0.01$ & $297 \pm 34$ & $15 \pm 5$ & $44 \pm 16$ \\
\hline Blank THP-T80-LNCs & $26.7 \pm 1.2$ & $0.08 \pm 0.02$ & - & - & - \\
\hline THP-T80-LNCs & $26.5 \pm 0.5$ & $0.08 \pm 0.01$ & $537 \pm 54$ & $88 \pm 3$ & $472 \pm 64$ \\
\hline Freeze-dried THP-T80-LNCs & $26.0 \pm 0.4$ & $0.09 \pm 0.01$ & $555 \pm 75$ & $9 \pm 2$ & $51 \pm 12$ \\
\hline
\end{tabular}

Note: Size, $\mathrm{Pl}$, encapsulation efficiency, drug payload, and total decitabine concentration in the formulation are expressed as the mean \pm SD ( $\mathrm{n}=3$ ).

Abbreviations: LNC, lipid nanocapsule; THP, Transcutol ${ }^{\circledast}$ HP; T80, Tween ${ }^{\circledR} 80$; PI, polydispersity index.

Kolliphor $^{\circledR} \mathrm{HS} 15,2.0 \%$ (w/w) NaCl, and 35.3\%(w/w) water. The volume of water for the tempering was $5 \mathrm{~mL}$. The size and PI of blank THP-LNCs were $33.6 \pm 1.6 \mathrm{~nm}$ and $0.09 \pm 0.01$, respectively (Table 2 ).

Decitabine was solubilized in THP and added to the formulation during the last cooling step to obtain the decitabineloaded THP-LNC formulation. Size, PI, total decitabine concentration, encapsulation efficiency, and drug loading are presented in Table 2. Decitabine-loaded THP-LNCs had a mean diameter of $33.6 \mathrm{~nm}$ and a PI $<0.10$, indicating a narrow size distribution.

Recovery of the decitabine incorporated in the formulation was $96 \% \pm 11 \%$. However, the encapsulation efficiency was too low (15\%) and drug loading was insufficient, a new LNC formulation was thus developed. The initially developed LNCs with Labrafac ${ }^{\circledR}$ WL1349 were used, and a mixture of THP and Tween ${ }^{\circledR} 80$ was added during the last cooling cycle, just before tempering, to obtain the THP-T80LNC formulation.

Blank THP-T80-LNCs had a size of $<30 \mathrm{~nm}$ and a PI of $<0.10$, indicating a narrow size distribution (Table 2). This size was confirmed by TEM analysis, and a spherical morphology of LNCs was observed (Figure 2). Decitabine was solubilized in the THP-T80 mixture and added during the last cooling cycle, before tempering, to obtain the decitabine-loaded THP-T80-LNC formulations. Size, PI, total decitabine concentration, encapsulation efficiency, and drug loading are presented in Table 2. The size and PI of decitabine-loaded formulations were not modified relative to the blank formulations, as for the THP-LNCs. Recovery of the incorporated decitabine in the formulation was $96 \% \pm 10 \%$, and the drug payload was $472 \pm 64 \mu \mathrm{g} / \mathrm{g}$ of the formulation. The THP-T80-LNC formulation was used for in vitro drug release and cell experiments.

Decitabine is sensitive to hydrolysis. Storage of decitabineloaded THP-T80-LNCs at $4^{\circ} \mathrm{C}$ for 4 days decreased the total decitabine concentration to $118 \pm 3 \mu \mathrm{g} / \mathrm{mL}$. The ability of THP-T80-LNCs to support freeze-drying was tested, in order to avoid water contact in the formulation. Freeze-drying removed approximately $75 \%$ of the water volume from the formulation.

The size and PI of freeze-dried decitabine-loaded THPT80-LNCs were analyzed for 5 months. After reconstitution in water, the size, PI, and total decitabine concentration were similar to the values obtained before freeze-drying at the different times tested (Figure 3). However, the encapsulation efficiency and drug payload were reduced by a factor of 9 (Table 2).

\section{In vitro release of the decitabine}

The release of decitabine-loaded THP-T80-LNCs relative to free-decitabine in PBS under submersion conditions was performed (Figure 4). There was significantly a slower release from decitabine-loaded THP-T80-LNCs than freedecitabine into the PBS, with no burst effect. Approximately $70 \%$ of the decitabine was released from THP-T80-LNCs after 24 hours and reached a plateau, whereas a total release of free-decitabine was observed, indicating retention of decitabine in THP-T80-LNCs. After 24 hours, the residual concentration of decitabine into the Float-a-Lyzer ${ }^{\circledR}$ device
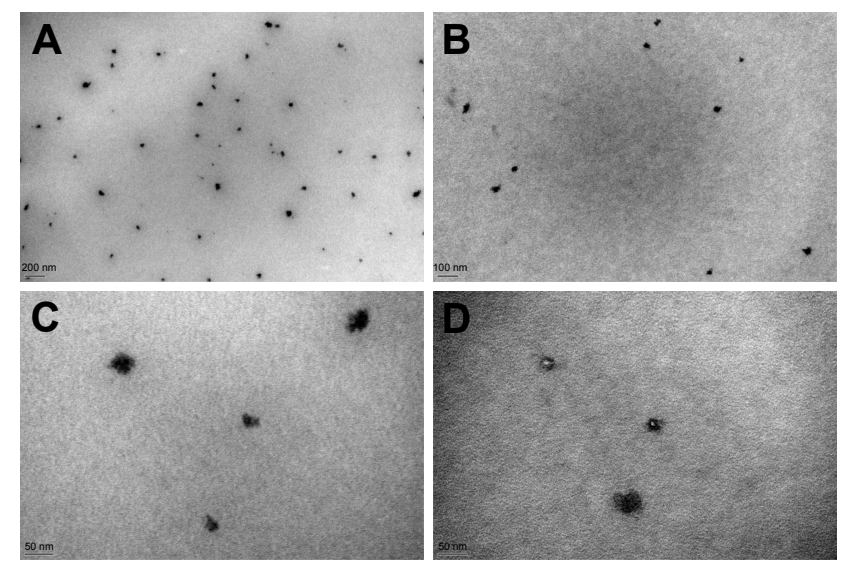

Figure 2 TEM micrographs of blank THP-T80-LNCs.

Note: The scale bars represent $200 \mathrm{~nm}$ (A), $100 \mathrm{~nm}$ (B), or $50 \mathrm{~nm}$ (C) and (D). Abbreviations: LNC, lipid nanocapsule; THP, Transcutol ${ }^{\circledR}$ HP; T80, Tween ${ }^{\circledR} 80$. 


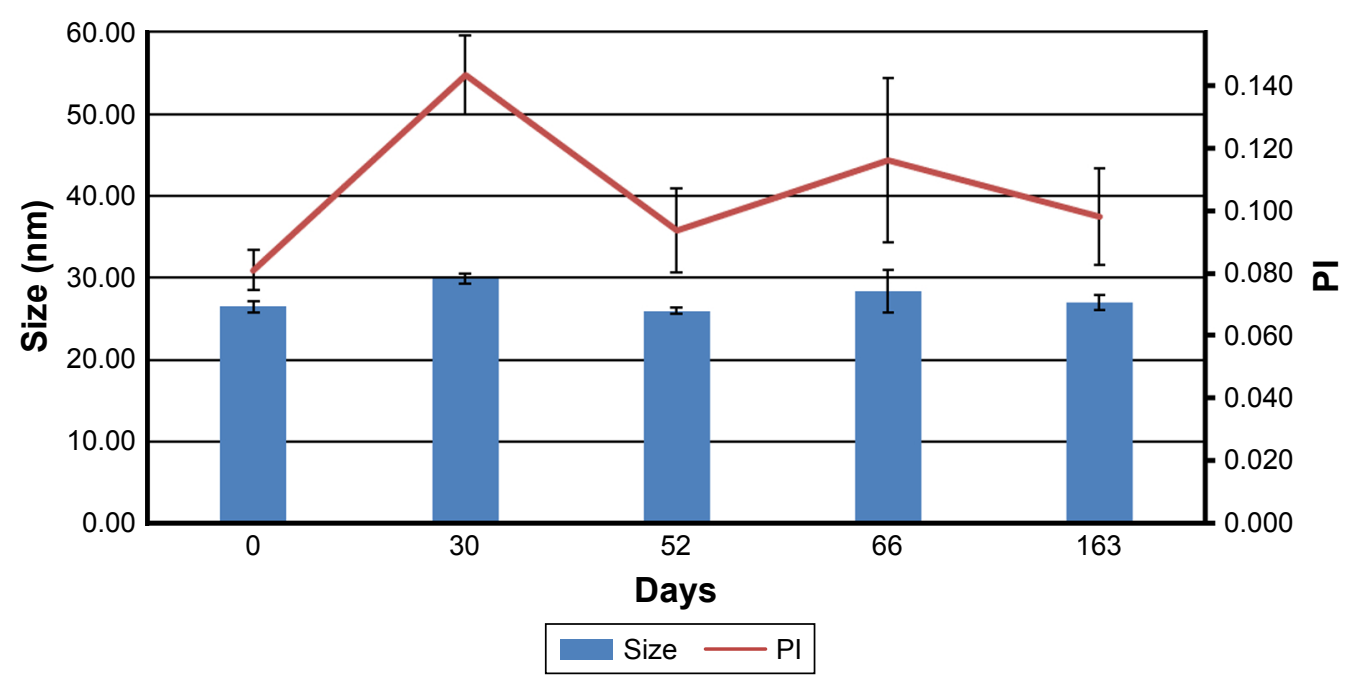

Figure 3 Stability study of freeze-dried blank THP-T80-LNCs over time.

Notes: Formulations were freeze dried and kept frozen at $-20^{\circ} \mathrm{C}(n=3)$. Size and PI were measured after water reconstitution.

Abbreviations: LNC, lipid nanocapsule; THP, Transcutol ${ }^{\circledR} \mathrm{HP}$; T80, Tween ${ }^{\circledR} 80$; PI, polydispersity index.

for the decitabine-loaded THP-T80-LNCs was estimated to be $26 \pm 12 \%$. The initial quantity of decitabine incorporated during the experiment was thus recovered.

\section{Decitabine stability in human plasma}

An enzyme degradation study of free-decitabine and decitabine-loaded THP-T80-LNCs in human plasma from healthy volunteers where cytidine deaminase is presented was performed. Decitabine loaded in THP-T80-LNCs was protected from cytidine deaminase degradation (Figure 5). Fifty percent of free-decitabine was degraded after 4 hours in human plasma, whereas a degradation of $35 \%$ was observed when decitabine was encapsulated in THP-T80-LNCs. This protection by THP-T80-LNCs was also observed after 6 hours.

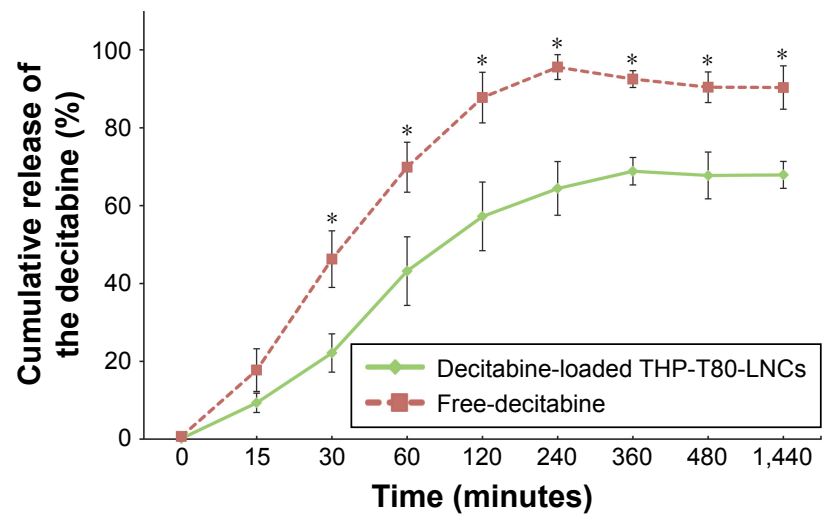

Figure 4 Decitabine release profile from THP-T80-LNCs in PBS pH 7.4.

Notes: Release of the decitabine loaded in THP-T80-LNCs was compared to that of free-decitabine $(n=3$, data are shown as the mean $\pm S D)$. ${ }^{*} p$-value $<0.05$.

Abbreviations: LNC, lipid nanocapsule; THP, Transcutol ${ }^{\circledR}$ HP; T80, Tween ${ }^{\circledR} 80$; $\mathrm{PI}$, polydispersity index.

\section{In vitro cytotoxicity of decitabine-loaded THP-T80-LNCs on AML cell lines}

Two AML cell lines were selected to evaluate the cytotoxicity of decitabine-loaded THP-T80-LNCs: HEL and HL60. HEL cells are more sensitive to decitabine than HL-60. ${ }^{26}$ Cell viability profiles after 3 days of treatment with blank THP-T80-LNCs, free-decitabine, or decitabineloaded THP-T80-LNCs are presented in Figure 6. Neither low concentrations $(1-50 \mathrm{nM})$ of free-decitabine nor decitabine-loaded THP-T80-LNCs altered the growth of HEL cells. Exposure to $100 \mathrm{nM}$ decitabine decreased HEL cell survival. The $\mathrm{IC}_{50}$ for decitabine-loaded THP-T80LNCs was $670 \mathrm{nM}$ and $>1,000 \mathrm{nM}$ for free-decitabine (Figure 6). There was no change in the viability of HEL

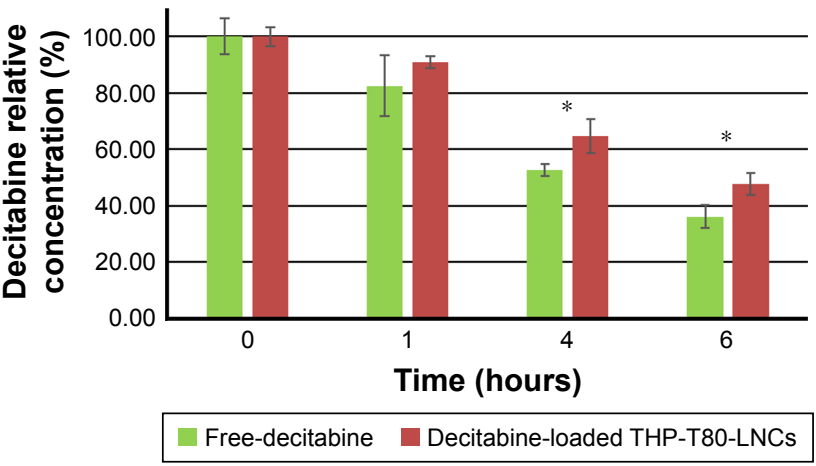

Figure 5 Stability profile of free-decitabine and decitabine-loaded THP-T80-LNCs in human plasma $(n=3$, data are shown as the mean $\pm S D)$.

Note: ${ }^{*} p$-value $<0.05$ for decitabine-loaded THP-T80-LNCs versus free-decitabine. Abbreviations: LNC, lipid nanocapsule; THP, Transcutol ${ }^{\circledR}$ HP; T80, Tween ${ }^{\circledR} 80$. 
A

THP-T80-LNCs concentrations $(\mu \mathrm{g} / \mathrm{mL})$

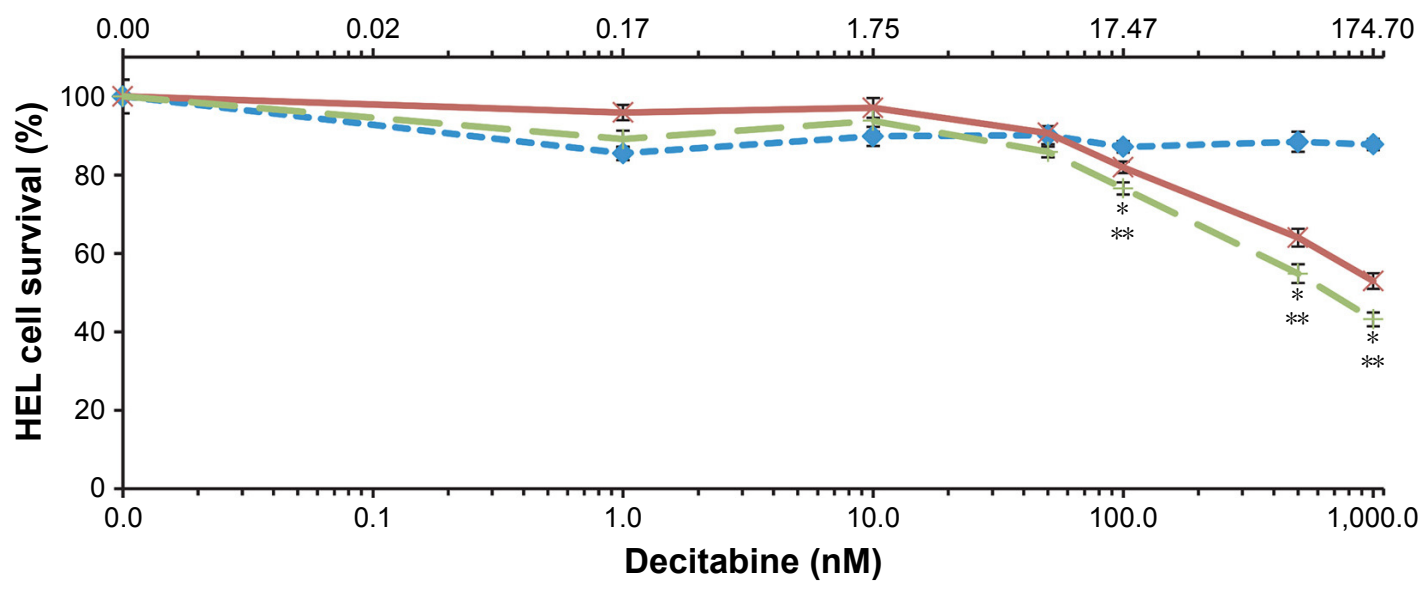

B

THP-T80-LNCs concentrations $(\mu \mathrm{g} / \mathrm{mL})$

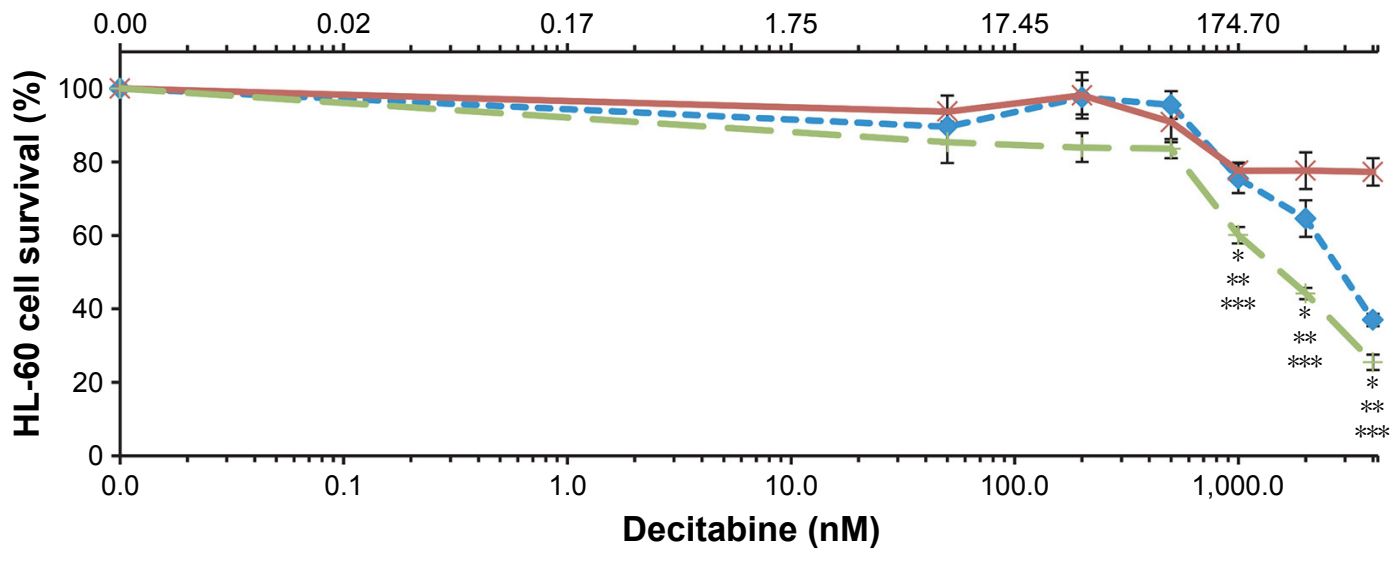

$-\curvearrowright$ Blank THP-T80-LNCs $\longleftarrow$ Free-decitabine $\longleftrightarrow$ - Decitabine-loaded THP-T80-LNCs

Figure 6 Cell viability following exposure of HEL (A) and HL-60 (B) cells to various concentrations of free-decitabine, blank THP-T80-LNCs, or decitabine-loaded THPT80-LNCs.

Notes: Data are expressed as the mean \pm SEM $(n=12)$. Results obtained for HEL and HL-60 cells with culture medium alone were considered to correspond to $100 \%$ survival. *P-value $<0.05$ for free-decitabine versus decitabine-loaded THP-T80-LNCs; ${ }^{* * P}$-value $<0.05$ for decitabine-loaded THP-T80-LNCs versus blank THP-T80-LNCs; $* * *$ P-value $<0.05$ for blank THP-T80-LNCs versus $100 \%$ survival.

Abbreviations: LNC, lipid nanocapsule; THP, Transcutol ${ }^{\circledR}$ HP; T80, Tween ${ }^{\circledR} 80$; SEM, standard error of the mean.

cells in the presence of blank THP-T80-LNCs, even at high concentrations.

The HL-60 cell survival study confirmed the resistance of these cells to free-decitabine, as cell survival only slightly decreased $(<20 \%)$ at concentrations $>1,000 \mathrm{nM}$. Decitabineloaded THP-T80-LNCs were more toxic, decreasing HL-60 viability with an IC50 of 1,537 nM. Blank THP-T80-LNCs also lowered HL60 viability, but significantly less than decitabineloaded THP-T80-LNCs, resulting in an IC50 of 471 versus 259 $\mu \mathrm{g} / \mathrm{mL}$ for decitabine-loaded THP-T80-LNCs (Figure 6).

\section{Cellular transport across Caco-2-cell monolayers}

Permeability of free-decitabine and decitabine-loaded THPT80-LNCs were evaluated across Caco-2 cell monolayers after 2 and 4 hours (Figure 7). There was no difference in permeability between free-decitabine and encapsulated decitabine after 2 hours. After 4 hours, the permeability of Caco-2-cell monolayers to decitabine-loaded THP-T80LNCs was significantly higher than that after 2 hours and to that of free-decitabine ( $p$-value $=0.039$ ).

\section{Discussion}

Decitabine is a hypomethylating agent recently authorized for the treatment of older AML patients. However, daily IV administration of decitabine is a very restrictive treatment. Contrary to EMA, FDA has not approved decitabine for AML treatment due to its lack of efficacy (the drug was only approved for myelodysplasic syndrome). ${ }^{6}$ This limitation may be due to its short half-life. Incorporation of decitabine in an 


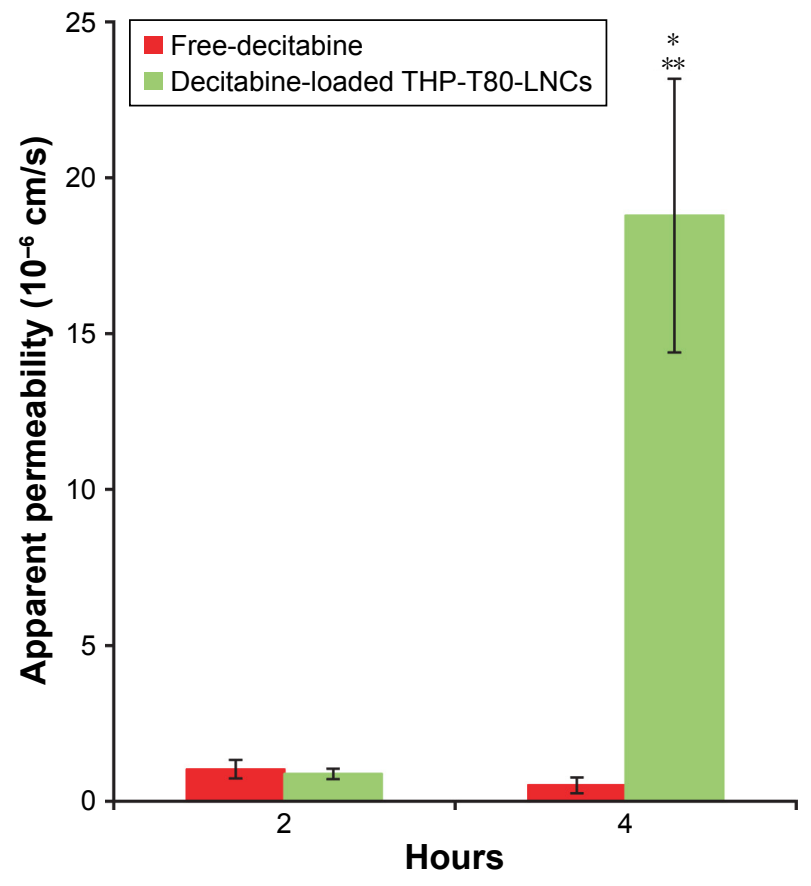

Figure 7 Apparent permeability of decitabine after 2 and 4 hours of incubation with $20 \mu \mathrm{M}$ free-decitabine or $20 \mu \mathrm{M}$ decitabine-loaded THP-T80-LNCs $(n=4)$. Notes: Data are expressed as the mean \pm SEM; ${ }^{*} P$-value $<0.05$ for free-decitabine versus decitabine-loaded THP-T80-LNCs; ${ }^{* * P}$-value $<0.05$ for 2 versus 4 hours. Abbreviations: LNC, lipid nanocapsule; THP, Transcutol ${ }^{\circledR}$ HP; T80, Tween ${ }^{\circledR} 80$; SEM, standard error of the mean.

LNC formulation may overcome this limitation. Moreover, decitabine treatment is only available via IV administration, mainly due to its low permeability, whereas the oral route would be more convenient for patients. Indeed, the oral route is compatible with treatment taken at home without the help of a nurse, ${ }^{11}$ reducing treatment costs relative to those for IV administration. An LNC formulation of decitabine may allow modification of the administration route.

The development of decitabine-LNC formulations requires validated analytical methods to characterize formulations and perform in vitro evaluations. Two analytical methods were developed and validated according to the ICH Q2 R1:24 an UPLC-UV method and a LC-MS/MS method. Compared to a previous published analytical method using HPLC-UV, ${ }^{27}$ the UPLC-UV method was able to reduce the runtime analysis (to 10 minutes versus 45 minutes). The UPLC-UV method for decitabine was linear in the $\mu \mathrm{g} / \mathrm{mL}$ range with an LOQ of $0.3 \mu \mathrm{g} / \mathrm{mL}$. This was not sufficiently sensitive for in vitro experiments. Thus, an LC-MS/MS method was developed and validated. A normal solid phase was used instead of the reverse $\mathrm{C}_{18}$ phase used in the UPLC-UV method, to increase the sensitivity of detection. Indeed, the obtained LOQ was $0.11 \mathrm{ng} / \mathrm{mL}$, an increase in sensitivity of $>25$-fold.

In comparison with other nanocarriers used to encapsulate decitabine, ${ }^{7-10}$ two free-organic solvent formulations were developed. Moreover, no chemical modification of decitabine was performed, thus not precluding its activity. Among Captex ${ }^{\circledR}$ 8000, Labrafil ${ }^{\circledR}$ M 1944 CS, Span ${ }^{\circledR}$ 80, THP, and Tween ${ }^{\circledR} 80$ used to produce LNCs, ${ }^{14,15,21-23}$ only THP or a mixture of THP-T80 were able to solubilize decitabine. The solubility of decitabine in THP has been previously shown by Neupane et al. ${ }^{10}$

THP has already been used in LNC formulations to encapsulate active lipophilic pharmaceutical ingredients, such as SN38 and etoposide, with high drug payloads. ${ }^{14,15}$ Overall, decitabine-LNC prototype formulations were investigated to obtain optimal decitabine loading. The quantity of THP was increased into the formulations to increase the quantity of incorporated decitabine. Moreover, during solubility study, a lower decitabine concentration in excipients was observed after 72 hours than after 2 hours. This may be due to the thermosensitivity of decitabine. ${ }^{4,28}$ To avoid a potential degradation of decitabine during the temperature cycles required for LNC formulation, decitabine was solubilized in THP in an ultrasonic bath at room temperature and added during the last cooling cycle, just before tempering with cold water. The addition of the drug during the last cooling cycle has already been used to encapsulate siRNA, known to be sensitive to high temperatures..$^{29}$ After formulation, the recovery of the decitabine was over $95 \%$, confirming the protection of decitabine from high temperatures during the formulation process. Decitabine-loaded THP-LNCs had a size of $33.6 \pm 1.6 \mathrm{~nm}$ and a drug payload of $44 \pm 16 \mu \mathrm{g} / \mathrm{mL}$, which was too low for therapeutic efficacy. In AML, the decitabine dosing schedule is $20 \mathrm{mg} / \mathrm{m}^{2}$ per day, requiring a volume over $450 \mathrm{~mL} / \mathrm{m}^{2}$ with this formulation. A minimum drug payload of $200 \mu \mathrm{g} / \mathrm{mL}$ (corresponding to $100 \mathrm{~mL} / \mathrm{m}^{2}$ ) would be required for therapeutic application.

The solubility of decitabine is higher in THP-T80 mixtures than in THP alone. Thus, an association between THP, Tween ${ }^{\circledR} 80$, and LNCs was tested to increase drug loading. A similar method using a mixture of Labrafac ${ }^{\circledR}$ WL1349 and $\operatorname{Span}^{\circledR} 85$ was previously used to encapsulate doxorubicin hydrochloride and erlotinib hydrochloride. ${ }^{21,22}$ However, decitabine was insoluble in a mixture of Labrafac ${ }^{\circledR}$ WL1349 and $\operatorname{Span}^{\circledR} 85$, and these compounds were replaced by a mixture of THP and Tween ${ }^{\circledR} 80$. Decitabine-loaded THP-T80-LNCs had a size of $26.5 \pm 0.5 \mathrm{~nm}$, which is smaller than the formulations developed by Vrignaud et al, combining $\operatorname{Span}^{\circledR} 85$ and Labrafac ${ }^{\circledR}$ WL1349 (LNC size of $80 \mathrm{~nm}$ ). ${ }^{21,22}$ They showed that the size of the final formulation was affected by the reverse formulation composition and correlated with the hydrophilic-lipophilic balance (HLB) of the surfactant used. ${ }^{21}$ Indeed, the HLB of Tween ${ }^{\circledR} 80$ is 15 , whereas it is 1.8 
for $\operatorname{Span}^{\circledR}$ 85. Moreover, THP, an ethylene oxide derivative, is more hydrophilic than Labrafac ${ }^{\circledR} \mathrm{W} 1349$, a triglyceride compound, confirming the hypothesis of Vrignaud et al on the strong correlation between the size of LNCs and hydrophilicity of the mixture associated with LNCs. ${ }^{22}$ A drug payload of $472 \pm 64 \mu \mathrm{g} / \mathrm{mL}$ and an encapsulation efficiency over $85 \%$ were finally obtained. This drug payload corresponds to an IV infusion volume of $42 \mathrm{~mL} / \mathrm{m}^{2}$ per day for AML treatment and could be considered for therapeutic application. This level of drug loading was compared to that of previous studies, in which nanostructured lipid carriers were developed. Drug loading ranged from $6 \%$ to $7 \% \mathrm{w} / \mathrm{w}$ for decitabine-loaded nanogels ${ }^{7}$ and was $8.54 \% \pm 2.65 \%$ in lipid-based nanocarriers developed by Neupane et al. ${ }^{10}$ The size obtained in our formulation was less than that of previously developed formulations, ranging from 80 to $200 \mathrm{~nm} .^{9,10,30,31}$ Paillard et al have demonstrated that the number of LNCs internalized into cells is inversely proportional to their size, ${ }^{32}$ suggesting that the size obtained for the THP-T80-LNC formulation could favor internalization. Moreover, no organic solvent was used and no decitabine-chemical modification was made in the THP-T80-LNC formulations, in contrast to previous formulations developed to encapsulate decitabine. , $^{90,30,31}$ The use of organic solvents may hamper the transfer of such strategies to a clinical scale. Due to these interesting properties, decitabine-loaded THP-T80-LNCs were selected and further characterizations were performed.

The decitabine was degraded when THP-T80-LNCs were stored in suspension at $4^{\circ} \mathrm{C}$, confirming its instability in water. ${ }^{4,28}$ A freeze-drying of decitabine-loaded THP-T80LNCs was then performed. The choice of cryoprotectant is fundamental to conserve LNC properties after thawing. Different cryoprotectants, including glucose, lactose, maltose, mannitol, mannose, sucrose, and trehalose were tested (data not shown). Among all cryoprotectants assayed, a 40\% w/w sucrose solution added in a $1: 1 \mathrm{v} / \mathrm{v}$ ratio with the formulation gave the best results, with no change in terms of size, PI, or total decitabine concentration. A high concentration of sucrose preserved the size of the particles after the freeze drying process, and a disaccharide, such as sucrose, worked better than monosaccharides. ${ }^{33}$ Contrary to previous observations on the LNC-freeze-drying process in the presence of trehalose, no modification of size was observed, despite the absence of lecithin, and THP-T80-LNCs can be freezedried. ${ }^{34}$ This observation was confirmed by Saliou et al who demonstrated the interest of PEG chains to act as stabilizers during freeze-drying. ${ }^{15}$ Freeze-drying conserved the physical characteristics of THP-T80-LNCs and preserved the total decitabine concentration, despite a residual content of water (25\% of the initial quantity), probably insufficient to hydrolyze decitabine during storage. The drug payload was however drastically decreased after this process. Thus, this method was not selected to stabilize the formulation, and currently, decitabine-loaded THP-T80-LNCs must be formulated extemporaneously.

It is known that high doses of decitabine are toxic in the clinic, whereas prolonging low doses are more effective, especially in AML patients, due to their poor hematological status. ${ }^{35,36}$ Encapsulation of a drug in carriers (microparticles or nanoparticles) is a strategy largely used to control drug release and decrease side effects. A release study using a Float-a-Lyzer ${ }^{\circledR}$ device, in $\mathrm{PBS} \mathrm{pH} 7.4$, in sink conditions, was performed to study the release kinetics of decitabine from LNCs. Decitabine was more slowly released from dialysis bags in the case of the decitabine-loaded THP-T80-LNCs than for free-decitabine, with no burst effect. After 24 hours, $\sim 70 \%$ of the decitabine was released from THP-T80-LNCs and reached a plateau, whereas the non-encapsulated decitabine was completely released. A very similar comparative profile was observed for previous formulations of decitabine nanoconjugates developed by Neupane et al. ${ }^{9,10}$ After 24 hours, $80 \%$ of the drug was released from nanocarriers, whereas it was fully released after 4 hours when not entrapped in nanocarriers. The slowed release of loaded decitabine confirms its retention in THP-T80-LNC nanocarriers. This could limit antitumor activity if this is confirmed in vivo. Although the in vitro experimental conditions tested have been largely described and used in the literature, they are not fully representative of in vivo conditions, and thus, this result should be confirmed in vivo.

The slowed release of decitabine encapsulated into THPT80-LNCs, which prolonged the contact of decitabine with cells, may be responsible for the stronger cytotoxic effect of decitabine-loaded THP-T80-LNCs relative to free-decitabine on non-resistant (HEL) and resistant (HL-60) AML cells. The improved cytotoxic effect may also be explained by the ability of LNCs to be internalized by cells via endocytosis. ${ }^{32}$ LNCs could thus facilitate the translocation of decitabine across the cellular membrane, which is generally carried out by nucleoside transporters, such as hENT1. 26,37,38 Thus, both the pathways could be used: free-drug through hENT 1 transport and decitabine-loaded THP-T80-LNCs through the endocytosis pathway. This property was also demonstrated, in various cancer cell lines, with a lipophilic-gemcitabine derivate loaded in solid lipid nanoparticles. ${ }^{39}$ A cell toxicity of THP-T80-LNCs was observed at high concentrations on HL-60 cells and was probably due to the presence of THP and Kolliphor ${ }^{\circledR}$ HS15 in THP-T80-LNCs composition, well known to be toxic at high concentration. ${ }^{40-42}$ 
Finally, older AML patients receive decitabine treatment through IV administration. The oral route may allow outpatient treatment and improve their quality of life. Moreover, it would help to reduce treatment costs, because oral administration does not require a qualified team. Nevertheless, the oral bioavailability of decitabine described in the literature is very low, $3.9 \%-14 \%,{ }^{43}$ probably due to its low permeability ( $\log P=-2.2)$ and its high hepatic metabolism limiting its half-life and oral administration.

Previous experiments have demonstrated the potential of LNCs for the oral administration of drugs. Apparent permeability of paclitaxel across a Caco- 2 cell monolayer when encapsulated into LNCs, increased by a factor of $>3.5,{ }^{44}$ which is consistent with an in vivo study that demonstrated a threefold improvement in the oral bioavailability of paclitaxel over that of the injectable solution. ${ }^{23}$ The strong correlation between the in vitro and in vivo models led us to study the apparent permeability of decitabine-loaded THP-T80-LNCs across Caco-2 cell monolayers. THP-T80-LNCs increased the transport of decitabine by a factor of $>30$ over that of free-decitabine. The mechanism used by THP-T80-LNCs to increase the Papp transport of decitabine across Caco- 2 cell monolayers is presently unknown. Neupane et al developed a lipid-decitabine conjugate, which was encapsulated into nanoparticles, and then they performed an ex vivo permeation study on a non-everted gut sac model. ${ }^{9}$ The Papp coefficient increased by a factor of 4 over that of a decitabine solution. According to authors, lipids and surfactants used in the formulations (Tween ${ }^{\circledR} 80$, Poloxamer 188, Labrasol ${ }^{\circledR}$, and Solutol ${ }^{\circledR}$ HS15) were able to inhibit P-glycoprotein, explaining the increase in permeability. However, no publication has demonstrated that decitabine is a substrate of P-glycoprotein. ${ }^{5}$ Lavelle et al administered a cytidine deaminase inhibitor, tetrahydrouridine, 1 hour before the oral administration of decitabine. ${ }^{45}$ Oral bioavailability was improved by a factor of 9, suggesting an important effect of cytidine deaminase on decitabine degradation. Indeed, decitabine is rapidly metabolized by cytidine deaminase, which is its main degradation pathway ${ }^{46}$ Cytidine deaminase is present in human plasma. A decitabine stability study was also performed in human plasma, which showed that THP-T80-LNCs were able to protect decitabine from cytidine deaminase degradation. Roger et al showed that LNCs were uptaken by Caco- 2 cells mainly via active endocytic processes and more particularly via clathrin-dependent and caveolae-dependent transport mechanisms. ${ }^{44}$ Moreover, the same authors observed that the integrity of LNCs is preserved after Caco-2 internalization through fluorescence resonance energy transfer analysis. ${ }^{47}$ These data suggest that the protection of the decitabine by THP-T80-LNCs against cytidine deaminase and the internalization of LNCs by Caco- 2 cells may improve gastrointestinal crossing of the drug. Given that LNCs remain intact throughout Caco-2 passage, the enhanced cytotoxic activity of encapsulated decitabine against AML cells may be conserved after intestinal absorption.

\section{Conclusion}

A formulation combining a mixture of THP-T80 and LNCs was able to efficiently encapsulate a hydrophilic drug, decitabine, without chemical modification of the drug or the use of organic solvents. The drug payload was over $450 \mu \mathrm{g} / \mathrm{mL}$ and the toxicity against two AML cell lines of the decitabine loaded in THP-T80-LNCs was enhanced over that of free-decitabine. The increased permeability of decitabine-loaded THP-T80-LNCs across a Caco-2 cell monolayer suggests the potential use of this formulation for oral administration.

Studies to evaluate the activity and pharmacokinetic parameters of decitabine-loaded THP-T80-LNCs in in vivo models of AML should now be considered.

\section{Acknowledgments}

The authors are very grateful to the Ligue contre le Cancer and particularly to the Maine et Loire and Charente-Maritime committees for their financial support.

The authors thank the SCIAM (Service Commun d'Imageries et d'Analyses Microscopiques) of Angers (France) for the TEM analysis.

\section{Disclosure}

The authors report no conflicts of interest in this work.

\section{References}

1. Rodriguez-Abreu D, Bordoni A, Zucca E. Epidemiology of hematological malignancies. Ann Oncol. 2007;18(1):i3-i8.

2. Alibhai SM, Leach M, Minden MD, Brandwein J. Outcomes and quality of care in acute myeloid leukemia over 40 years. Cancer. 2009;115(13): 2903-2911.

3. Stresemann C, Lyko F. Modes of action of the DNA methyltransferase inhibitors azacytidine and decitabine. Int J Cancer. 2008;123(1): $8-13$.

4. Lin KT, Momparler RL, Rivard GE. High-performance liquid chromatographic analysis of chemical stability of 5-aza-2'-deoxycytidine. J Pharm Sci. 1981;70(11):1228-1232.

5. European Medicines Agency. Dacogen: summary of product characteristics. 2017. Available from: http://www.ema.europa.eu/docs/en_GB/ document_library/EPAR_-_Product_Information/human/002221/ WC500133569.pdf. Accessed June 1, 2017.

6. Nieto M, Demolis P, Behanzin E, et al. The European Medicines Agency Review of Decitabine (Dacogen) for the treatment of adult patients with acute myeloid leukemia: summary of the scientific assessment of the committee for medicinal products for human use. Oncologist. 2016; 21(6):692-700. 
7. Vijayaraghavalu S, Labhasetwar V. Efficacy of decitabine-loaded nanogels in overcoming cancer drug resistance is mediated via sustained DNA methyltransferase 1 (DNMT1) depletion. Cancer Lett. 2013; 331(1):122-129.

8. Cui Y, Naz A, Thompson DH, Irudayaraj J. Decitabine nanoconjugate sensitizes human glioblastoma cells to temozolomide. Mol Pharm. 2015;12(4):1279-1288.

9. Neupane YR, Sabir MD, Ahmad N, Ali M, Kohli K. Lipid drug conjugate nanoparticle as a novel lipid nanocarrier for the oral delivery of decitabine: ex vivo gut permeation studies. Nanotechnology. 2013; 24(41):415102-415113.

10. Neupane YR, Srivastava M, Ahmad N, Kumar N, Bhatnagar A, Kohli K. Lipid based nanocarrier system for the potential oral delivery of decitabine: formulation design, characterization, ex vivo, and in vivo assessment. Int J Pharm. 2014;477(1-2):601-612.

11. Roger E, Lagarce F, Garcion E, Benoit JP. Biopharmaceutical parameters to consider in order to alter the fate of nanocarriers after oral delivery. Nanomedicine (Lond). 2010;5(2):287-306.

12. Heurtault B, Saulnier P, Pech B, Proust JE, Benoit JP. A novel phase inversion-based process for the preparation of lipid nanocarriers. Pharm Res. 2002;19(6):875-880.

13. Huynh NT, Passirani C, Saulnier P, Benoit JP. Lipid nanocapsules: a new platform for nanomedicine. Int J Pharm. 2009;379(2):201-209.

14. Roger E, Lagarce F, Benoit JP. Development and characterization of a novel lipid nanocapsule formulation of $\mathrm{Sn} 38$ for oral administration. Eur J Pharm Biopharm. 2011;79(1):181-188.

15. Saliou B, Thomas O, Lautram N, et al. Development and in vitro evaluation of a novel lipid nanocapsule formulation of etoposide. Eur J Pharm Sci. 2013;50(2):172-180.

16. Eissa MM, El-Moslemany RM, Ramadan AA, Amer EI, El-Azzouni MZ, El-Khordagui LK. Miltefosine lipid nanocapsules for single dose oral treatment of Schistosomiasis mansoni: a preclinical study. PLoS One. 2015;10(11):e0141788.

17. Laine AL, Clavreul A, Rousseau A, et al. Inhibition of ectopic glioma tumor growth by a potent ferrocenyl drug loaded into stealth lipid nanocapsules. Nanomedicine. 2014;10(8):1667-1677.

18. Ramadan A, Lagarce F, Tessier-Marteau A, et al. Oral fondaparinux: use of lipid nanocapsules as nanocarriers and in vivo pharmacokinetic study. Int J Nanomedicine. 2011;6:2941-2951.

19. Messaoudi K, Saulnier P, Boesen K, Benoit JP, Lagarce F. Antiepidermal growth factor receptor siRNA carried by chitosantransacylated lipid nanocapsules increases sensitivity of glioblastoma cells to temozolomide. Int J Nanomedicine. 2014;9:1479-1490.

20. Morille M, Montier T, Legras P, et al. Long-circulating DNA lipid nanocapsules as new vector for passive tumor targeting. Biomaterials. 2010; 31(2):321-329.

21. Vrignaud S, Anton N, Gayet P, Benoit JP, Saulnier P. Reverse micelleloaded lipid nanocarriers: a novel drug delivery system for the sustained release of doxorubicin hydrochloride. Eur J Pharm Biopharm. 2011; 79(1):197-204.

22. Vrignaud S, Hureaux J, Wack S, Benoit JP, Saulnier P. Design, optimization and in vitro evaluation of reverse micelle-loaded lipid nanocarriers containing erlotinib hydrochloride. Int J Pharm. 2012;436(1-2):194-200.

23. Peltier S, Oger JM, Lagarce F, Couet W, Benoit JP. Enhanced oral paclitaxel bioavailability after administration of paclitaxel-loaded lipid nanocapsules. Pharm Res. 2006;23(6):1243-1250.

24. International Conference on Harmonization. Validation of analytical procedures: text and methodology (Q2 R1). 2005. Available from: http:// www.ich.org/fileadmin/Public_Web_Site/ICH_Products/Guidelines/Quality/Q2_R1/Step4/Q2_R1_Guideline.pdf. Accessed February 1, 2017.

25. Reed LJ, Muench H. A simple method of estimating fifty per cent endpoints. Am J Epidemiol. 1938;27(3):493-497.

26. Qin T, Jelinek J, Si J, Shu J, Issa JP. Mechanisms of resistance to 5-aza-2'deoxycytidine in human cancer cell lines. Blood. 2009;113(3):659-667.

27. Neupane YR, Srivastava M, Ahmad N, Soni K, Kohli K. Stability indicating RP-HPLC method for the estimation of decitabine in bulk drug and lipid based nanoparticles. Int J Pharm Sci Res. 2014;7:294-302.
28. Hua W, Ierardi T, Lesslie M, Hoffman BT, Mulvana D. Development and validation of a HILIC-MS/MS method for quantification of decitabine in human plasma by using lithium adduct detection. $J$ Chromatogr B. 2014;969:117-122.

29. David S, Resnier P, Guillot A, Pitard B, Benoit JP, Passirani C. siRNA LNCs - a novel platform of lipid nanocapsules for systemic siRNA administration. Eur J Pharm Biopharm. 2012;81(2):448-452.

30. Li SY, Sun R, Wang HX, et al. Combination therapy with epigenetictargeted and chemotherapeutic drugs delivered by nanoparticles to enhance the chemotherapy response and overcome resistance by breast cancer stem cells. J Control Release. 2015;205:7-14.

31. Su X, Wang Z, Li L, et al. Lipid-polymer nanoparticles encapsulating doxorubicin and 2'-deoxy-5-azacytidine enhance the sensitivity of cancer cells to chemical therapeutics. Mol Pharm. 2013;10(5): 1901-1909.

32. Paillard A, Hindre F, Vignes-Colombeix C, Benoit JP, Garcion E. The importance of endo-lysosomal escape with lipid nanocapsules for drug subcellular bioavailability. Biomaterials. 2010;31(29):7542-7554.

33. Howard MD, Lu X, Jay M, Dziubla TD. Optimization of the lyophilization process for long-term stability of solid-lipid nanoparticles. Drug Dev Ind Pharm. 2012;38(10):1270-1279.

34. Dulieu C, Bazile D. Influence of lipid nanocapsules composition on their aptness to freeze-drying. Pharm Res. 2005;22(2):285-292.

35. Karahoca M, Momparler RL. Pharmacokinetic and pharmacodynamic analysis of 5-aza-2'-deoxycytidine (decitabine) in the design of its doseschedule for cancer therapy. Clin Epigenetics. 2013;5(1):3.

36. He PF, Zhou JD, Yao DM, et al. Efficacy and safety of decitabine in treatment of elderly patients with acute myeloid leukemia: a systematic review and meta-analysis. Oncotarget. 2017;8(25):41498-41507.

37. Arimany-Nardi C, Errasti-Murugarren E, Minuesa G, et al. Nucleoside transporters and human organic cation transporter 1 determine the cellular handling of DNA-methyltransferase inhibitors. Br J Pharmacol. 2014;171(16):3868-3880

38. Ueda K, Hosokawa M, Iwakawa S. Cellular uptake of decitabine by equilibrative nucleoside transporters in HCT116 Cells. Biol Pharm Bull. 2015;38(8):1113-1119.

39. Lansakara PD, Rodriguez BL, Cui Z. Synthesis and in vitro evaluation of novel lipophilic monophosphorylated gemcitabine derivatives and their nanoparticles. Int J Pharm. 2012;429(1-2):123-134.

40. Sullivan DW Jr, Gad SC, Julien M. A review of the nonclinical safety of Transcutol(R), a highly purified form of diethylene glycol monoethyl ether (DEGEE) used as a pharmaceutical excipient. Food Chem Toxicol. 2014;72:40-50

41. Le Roux G, Moche H, Nieto A, Benoit JP, Nesslany F, Lagarce F. Cytotoxicity and genotoxicity of lipid nanocapsules. Toxicol In Vitro. 2017; 41:189-199.

42. Maupas C, Moulari B, Beduneau A, Lamprecht A, Pellequer Y. Surfactant dependent toxicity of lipid nanocapsules in $\mathrm{HaCaT}$ cells. Int J Pharm. 2011;411(1-2):136-141.

43. Liu D. Recent advances in myelodysplasia: update from 2011 ASH annual meeting. J Hematol Oncol. 2012;5:A4.

44. Roger E, Lagarce F, Garcion E, Benoit JP. Lipid nanocarriers improve paclitaxel transport throughout human intestinal epithelial cells by using vesicle-mediated transcytosis. J Control Release. 2009;140(2): 174-181.

45. Lavelle D, Vaitkus K, Ling Y, et al. Effects of tetrahydrouridine on pharmacokinetics and pharmacodynamics of oral decitabine. Blood. 2012; 119(5):1240-1247.

46. Issa JP, Roboz G, Rizzieri D, et al. Safety and tolerability of guadecitabine (SGI-110) in patients with myelodysplastic syndrome and acute myeloid leukaemia: a multicentre, randomised, dose-escalation phase 1 study. Lancet Oncol. 2015;16(9):1099-1110.

47. Roger E, Gimel JC, Bensley C, Klymchenko AS, Benoit JP. Lipid nanocapsules maintain full integrity after crossing a human intestinal epithelium model. J Control Release. 2017;253:11-18. 


\section{Supplementary materials}

Table SI Gradient elution of the UPLC-UV method

\begin{tabular}{llll}
\hline Time (minutes) & Phase A (\%) & Phase B (\%) & Flow (mL/minutes) \\
\hline 2.5 & 100 & 0 & 0.6 \\
4 & 20 & 80 & 0.6 \\
6 & 20 & 80 & 0.6 \\
8 & 100 & 0 & 0.3 \\
9 & 100 & 0 & 0.6 \\
10 & 100 & 0 & 0.6 \\
\hline
\end{tabular}

Note: Phase $A$ was composed of water and phase $B$ of methanol.

Abbreviation: UPLC-UV, ultra-high-performance liquid chromatography.

Table S2 Gradient elution of the LC-MS/MS method

\begin{tabular}{llll}
\hline Time (minutes) & Phase A (\%) & Phase B (\%) & Flow (mL/minutes) \\
\hline 0.00 & 20 & 80 & 0.200 \\
6.00 & 28 & 72 & 0.200 \\
6.10 & 28 & 72 & 0.300 \\
7.00 & 20 & 80 & 0.300 \\
12.00 & 20 & 80 & 0.300 \\
\hline
\end{tabular}

Note: Mobile Phase $A$ was composed of a mixture of ammonium acetate $10 \mathrm{mM}$ and $0.1 \%$ formic acid $\mathrm{v} / \mathrm{v}$, and mobile phase $B$ acetonitrile and $0.1 \%$ formic acid $\mathrm{v} / \mathrm{v}$.

A $\quad 0.180$

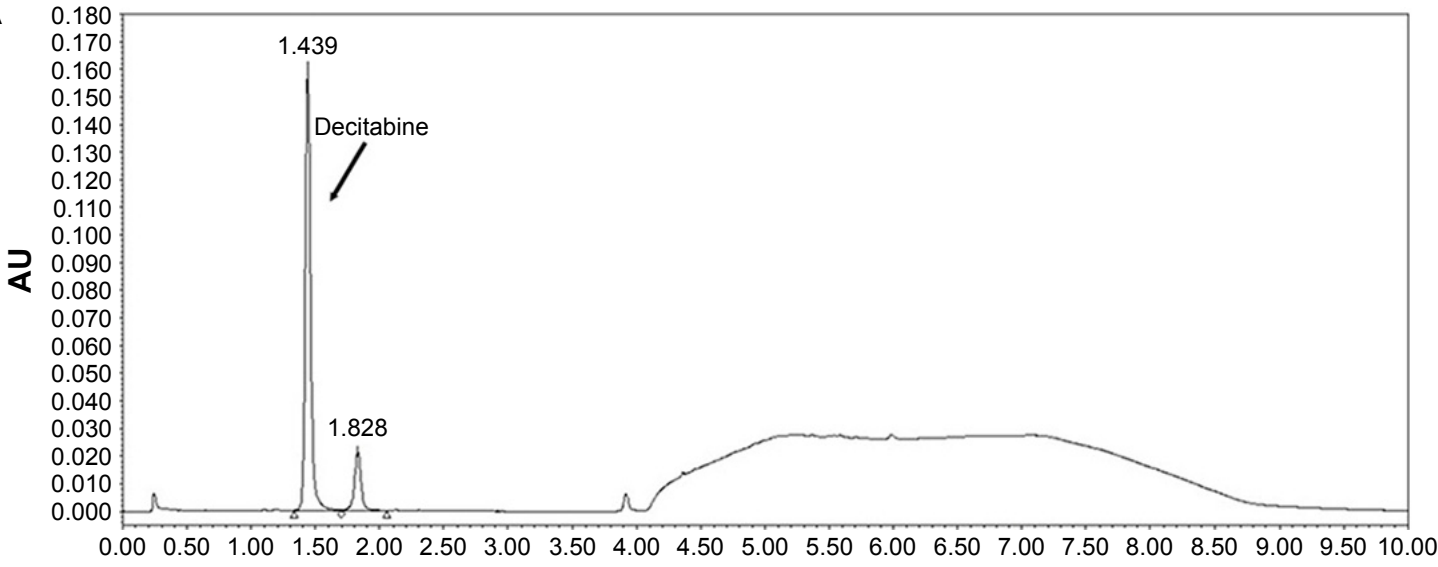

Minutes

Figure SI (Continued) 
B
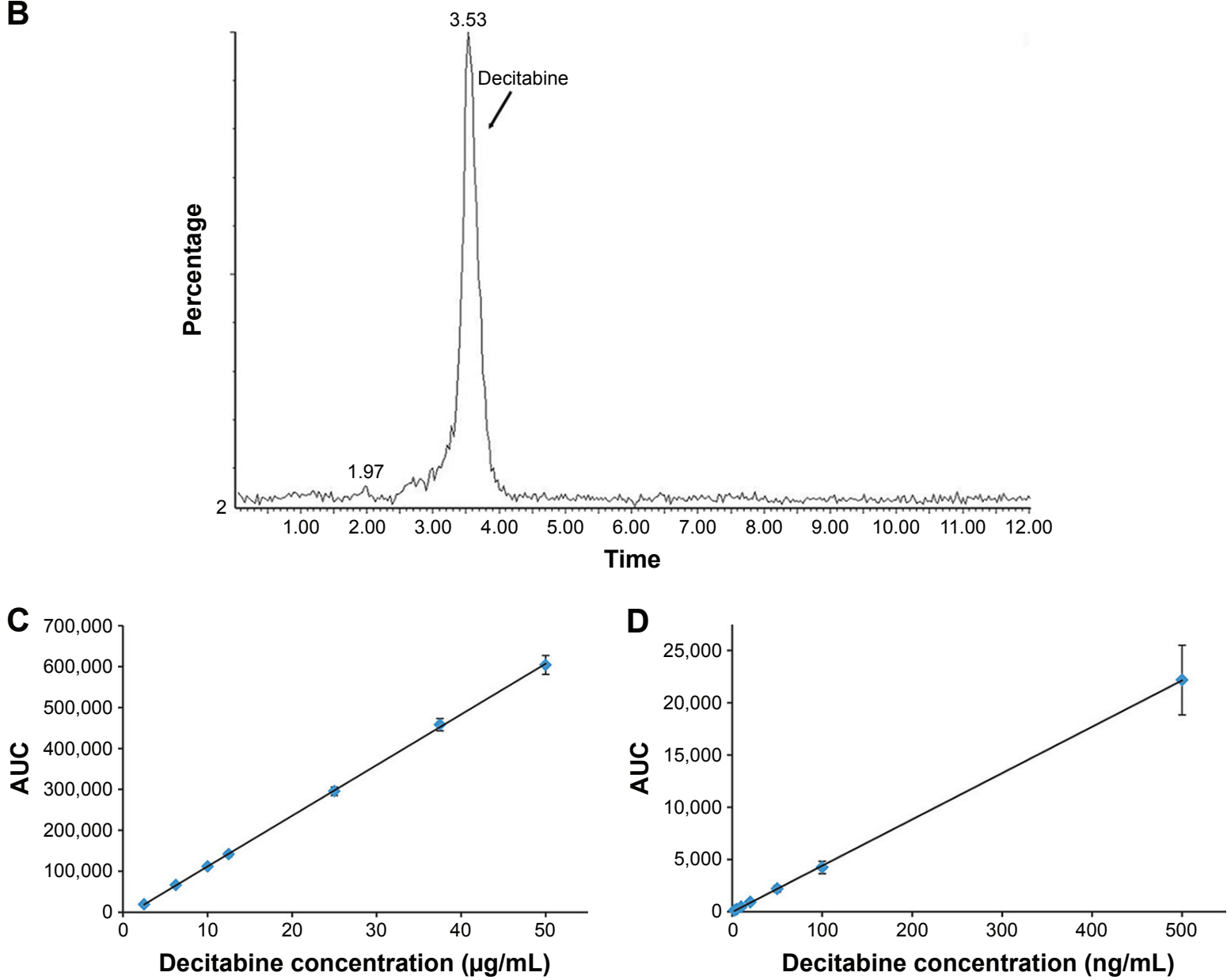

Figure SI Chromatograms of a $40 \mu \mathrm{g} / \mathrm{mL}$ decitabine solution analyzed by the UPLC-UV method (A), a $20 \mathrm{ng} / \mathrm{mL}$ decitabine solution analyzed by the LC-MS/MS method (B), and mean calibration curves of the UPLC-UV method (C) and LC-MS/MS method (D).

Abbreviation: UPLC-UV, ultra-high-performance liquid chromatography.

\section{Publish your work in this journal}

The International Journal of Nanomedicine is an international, peerreviewed journal focusing on the application of nanotechnology in diagnostics, therapeutics, and drug delivery systems throughout the biomedical field. This journal is indexed on PubMed Central, MedLine, CAS, SciSearch ${ }^{\circledR}$, Current Contents ${ }^{\circledR} /$ Clinical Medicine,
Journal Citation Reports/Science Edition, EMBase, Scopus and the Elsevier Bibliographic databases. The manuscript management system is completely online and includes a very quick and fair peer-review system, which is all easy to use. Visit http://www.dovepress.com/ testimonials.php to read real quotes from published authors. 